\title{
STUDY OF PERCEPTIONS AND THE ROLE OF ESP TEACHERS ABOUT EFFECTIVENESS OF ESP COURSES IN LANGUAGE TEACHER EDUCATION DURING PRE-AND IN-SERVICE TEACHING PRACTICE
}

\author{
Houman Bijani \\ Assistant professor, English Language Department, Islamic Azad University, Zanjan Branch, Zanjan, Iran \\ Nesa Artishehdar \\ MA Student at TEFL \\ English Language Department, Islamic Azad University, ZanjanBranch,Zanjan, Iran \\ Fatemeh Najafi \\ MA Student at TEFL \\ English Language Department, Islamic Azad University, ZanjanBranch,Zanjan,Iran
}

\begin{abstract}
It is believed that the time that the undergraduate students register in Teacher Education Program they have an extensive amount of experience, but English for specific purpose (ESP) teachersor pre-service ESP teachers are regarded as valuable resources for recognizing attitudes or perceptions of effectiveness of ESP teachers whose classless are taught by them. Pre-service teachers surely have several specific perceptions about their future career and the effectiveness of ESP teachers whose classes are being taught by them during practice teaching. If ESP teachers are asked the question why do you want to be anESP teacher? They may have different responses such as: I want to be an ESP teacher because I have a very good image of my teachers during my school period or I want to be a ESP teacher because I would like to follow the methods and procedures of effective teaching that my university teachers did during teaching specific courses. However, some might have an opposite perception. Anyway, this study tries to compare the perceptions of ESP teachers before (pre-service) and after (in-service) teaching period.
\end{abstract}

Keywords: ESP; ESP teachers; Pre-service and In-service teachers; ESP teachers' perceptions

\section{Council for Innovative Research}

Peer Review Research Publishing System

Journal: Journal of Advances in Linguistics

vol 5 No 2

editor@cirjal.com

www.cirjal.com, www.cirworld.com 


\section{Introduction}

It appears that Teacher Education Program is the most widely accepted and administrated program in most of universities worldwide for educating and training ESP and other educational institute teachers. Moreover, when the undergraduate students register in Teacher Education Program they have already attended for at least twelve years and have a great amount of schooling experience. teachersESP or pre-service teachers are regarded as valuable resources for recognizing attitudes or perceptions of effectiveness of ESP teachers whose classless are taught by them. Student teachers surely have several specific perceptions about their future career and the effectiveness of school teachers whose classes are being taught by them during practice teaching. If student teachers are asked the question why do you want to be anESP teacher? They may have different responses such as: I want to be teacher because I have a very good image of my teachers during my school period or I want to be a teacher because I would like to follow the methods and procedures of effective teaching that my school teachers did. However, some might have an opposite perception. They would like to be teachers because they want to be more successful and effective than their own teachers. Whatever perceptions they have, there is a fact taken for granted. All student teachers during pre-service program have some perceptions and attitudes which might date back to their schooling period or might shape during the period being engaged in program through collaboration with their teacher educators and peers and taking part in actual teaching practice. School teachers play a crucial role in having a great impact on their students and consequently on student teachers' perception of actual teaching practice. The schooling experience has the potential to last a long time and would be influential in student teachers' forthcoming decisions. There are different issues which make concerns to ESP teachers. In this part, I will consider some of the concerns and perceptions that ESPteachers might have about school teachers' actual teaching in ESP classroom setting in advance. Theses perceptions are as follows:

1. Their perceptions of how to write and implement ESP lesson plans

2. Their perceptions of how to adapt toESP students' needs

3. Their perceptions ofESP classroom management

4. Their perceptions of how to deal with excessive ESP materials

5. Their perception of how to manage the ambiguous situations inESP actual teaching

6 . Their perceptions of how to be reflective inESP actual teaching

8. Their perceptions of how to deal with ESPstudents' expectations and purposes

9. Their perceptions of how to deal withESP students' success

10. Their perceptions of having a role model forESP teaching

11. Their perceptions of how to enjoy their work and their students

\section{Aims of the Study}

Generally speaking, the aim of this study is identify what sort of perceptions ESP teachers of English language teaching have towards the effectiveness of school teachers whose classes are taught by them. Specifically speaking, the purpose of study is to identify which of the eleven aforementioned perceptions are taking place in actual teaching. In other words, the study tries to discover which of the perceptions are considered as the criteria of effectiveness of school teachers' classes taught by them. It also attempts to find out if ESP teachers keep their perceptions of effective teaching or they revise it based on their new experience of ESP actual teaching practice.

\section{Research Questions}

1. What are the perceptions of ESP teachers towards effective school teachers and their classes during teacher education program?

2. What are the perceptions of ESP teachers towards effective school teachers and their classes after taking part in actual teaching practice in their classes?

3. Is there any significant relationship between ESP teachers before teaching practice perceptions and after teaching practice perceptions?

\section{Significance of the Study}

Before attending any sort of ESP actual teaching in real life schools, the attitudes and perceptions that ESP teachers have, are mostly based on their schooling experience and the theoretical considerations which are far from what happens in the actual classroom practice. The perceptions of lesson plans, classroom management, teachers' reflection, excessive materials and tasks, adaptation to students' needs and expectations, managing ambiguous situations, considering the ultimate goals of teaching and enjoying students and work all are crucial to the effectiveness of school teachers in actual classroom practice. Having perceptions of these points during teacher education program and before attending any actual practice is a different point from their perception in real teaching practice. Thus understanding ESP teachers' before and after teaching practice perception of the effectiveness of school teachers teaching practice is substantial to the success of their future career. 


\section{Review of Literature}

Scholarship in effectiveness of school teachers teaching practice is thorough and intricate and has surveyed different issues in this area. Several scholars have studied the perceptions and attitudes of teacher educators, teachers, student teachers and students about the teaching effectiveness. The perceptions that student teachers have is considerably important to take into account. The difference between student teachers' perceptions of effective actual teaching before attending actual teaching practice has not thoroughly studied. Student teachers have various perceptions about effectiveness of school teachers teaching practice whose classes are taught by them. A number of perceptions which have been studied by scholars are elaborated in details. Theses perceptions will be the base of my research in discussing what perceptions student teachers have before and after attending teaching practice. They are described in details in following part:

\section{Their perceptions of how to write and implement lesson plans}

One of the important student teachers' perceptions of effectiveness of school teachers whose classes are being taught by them refers to how to write lesson plans and how to proceed it in the actual classroom setting. It appears that student teachers imagine that novice school teachers have problems in organizing and following the lesson plans in the first few years of their teaching practice. According to Bhargava (2009) "Things that are put down on paper do not always match up with realities of the classroom" (p.3). This fact provides a situation that student teachers in advance have the idea of being nervous as they have to rethink and redesign their imagined written lesson plan.

\section{Their perceptions of classroom management}

The issue of how to maintain the discipline in the classroom and how to deal with the classroom is one of the perceptions of student teachers regarding the actual classroom management. Novice teachers and sometimes even the experienced teachers face big challenges in managing the classroom in the most proper way. Hassett (2000) states that "Maintaining discipline in the classroom and dealing tactfully with the pupils who misbehave pose a challenge to student teacher". Student teachers have certainly come across classrooms taught by school teachers in which the misbehaviors of children have caused real challenges for school teachers. In this regard Bhargava (2009) argues that "In some of the schools visited by student teachers impish behavior of children cause disturbance in the class and impedes effective classroom management"(p.4).

\section{Their perceptions of having a role model for teaching}

One of the determining factors in school teachers' effectiveness rises from their schooling experience. Some novice teachers attempt to follow the procedures of their own school time teachers who had great effect on their lives and choosing their future profession. Student teachers might think back to their own teachers and identify to what extent their teaching has been shaped by their approaches of teaching. Feng (2000) asks these questions: Think of some of your teachers and find out how has your teaching process been shaped by their practices, consciously or unconsciously? Think also of the ineffective teachers that you had in schooling time teacher. Are there things that you don't like to follow in your teaching process because those were not welcomed by you and your peers in those times? McNergney and Keller (1999) believe that learning how to teach is a gradual process, and gets views and practices from different sources. School teachers are not always entirely aware of the effects of their teaching. Student teachers absorb ideas and practices from their teacher education program and their previous effective teachers. In actual teaching they might follow their beloved teachers' ways of teaching. Regarding the schooling experience, one of the perceptions of students teachers about the school teachers way of teaching refers to the focus of teaching in classroom setting which is mostly on the procedures employed for teaching skills rather than the effects of integrated teaching. In this regard Crozier, Menter and Pollard (1990) believe that "It has been observed that during teaching practice more emphasis remains on use of various teaching skills rather than on integrated impact of teaching"(p.10). Mostly student teachers try to follow the procedures and styles of their own teachers from their experience of schooling time but they do not pay attention to this fact that as a teacher they have their own identity and it is not pedagogically appropriate to imitate their teachers. According to Crozier, Menter and Pollard (1990) "Most of the student teachers imitate the style of their own teachers. But it is felt that student teacher's imitation and direct modeling is damaging to the development of teaching profession"(p.10).

\section{Their perceptions of how to deal with excessive materials}

Giving unreasonable importance to the quantity of the mistrials to be covered by school teachers during teaching practice in a specified time is one negative concern or perception that student teachers have dealing with the actual teaching practice. Constable and Norton (1994) argue that overloading school teachers with excessive materials provides an obstacle to the process of optimal teaching. They state that "The main focus of student teachers remains on finishing the task of 40 lesson plans and maintaining proper written records rather than on developing deep understanding and skills needed for their professional development"(p.18). Student teachers view teaching as a set of multi tasks. Student teachers assume that teachers have to spend their time to prepare lesson plans, prepare teaching equipments and assess the homework and some other activities. According to Stephens (1996), all these activities make them tired. He has pointed out how school teacher might have a feeling of panic if they get a feeling that they are not able to do a specific sort of activity or task in the classroom setting. Thus student perception of the amount of materials that school teachers are supposed to handle in a specific classroom time and the way school teachers deal with this issue is an important consideration for them in defining the effectiveness of teaching practice by school teachers who teach their own classes. 
Their perceptions of how to deal with students' expectations and purposes

Student teachers assume that school teachers should have a good sense of purpose. As a teacher, he or she should have a perfect understanding of students' expectations. With respect to those expectations, school teachers should provide plans so as to fulfill the requirements of students' needs and expectorations. As Hassett (2000) states "As a teacher, this means that you know what your students expect, and you make plans to meet those expectations. You, too, have expectations about what happens in your classroom, based on the goals you're trying to achieve" (p.23). An effectiveness of classroom practice requires school teachers to find out the purposes students are keeping. Different students with different needs and purposes surely require diverse methods and procedures so as to tackle them in a proper way. Student teachers perceptions of how to cope with theses purposes and needs of students is a challenging issue which would indicate how effective school teachers are in their classroom setting.

\section{Their perceptions of how to deal with students' success}

The question of how to determine the success of Students in the actual process of teaching and learning has always been a controversial issue. Student teachers' attitudes towards the criteria of identification of different students success is an important aspect of effectiveness of teaching practice. In this regard Darling-Hammond (2000) discusses "This is the great paradox of teaching. If we base our self-evaluation purely on the success of our students, we'll be disappointed" (p.44). In all levels of leaning especially in advanced levels, there are so many factors which present the students' various goals. How to guarantee the success of all students is a challenging job for school teachers. Student teachers during their pre-service program will consider the issue of how to tackle the issue of students' various criteria of success as an effective aspect of teaching in actual classroom setting. Regarding the effectiveness of teaching and the ways how to identify different students' successes, Hassett (2000) states that "The happy medium can be achieved with a simple question: Did I do everything that I could in this class, this time, to meet the needs of all my students, assuming that complete success was possible?"Then he concludes that as long as school teachers find out answers to this question, they are successful in providing a climate of success.

Their perception of how to manage the ambiguous situations in actual teaching

One of the perceptions of student teachers comes from the question of ambiguity in actual classroom setting and the way school teachers attempt to cope with this issue. Wenger (1998) says that one of the biggest challenges of school teachers come from the question of how to reflect on the immediate and on-the-spot educational events. It seems that effective teachers know the ropes and find out systematic approaches and procedures in dealing with ambiguous situations. According to Young (1998) lack of immediate and appropriate feedback to students is a challenging point for the success of school teachers in teaching and learning process. There is not a pre-determined way of predicting accurately what the long term outcomes of school teachers' teaching would be. In this regard Wenger (1999) concludes that if school teachers know how to manipulate the employment of materials and strategies and know how to nurture the expectations of success for all learners, school teachers will not come across the ambiguous and unpredictable situations. Paying more emphasis on what school teachers control and having collaborative and mutual relationships with students will provide good strategies so that school teachers will tackle ambiguous situations in actual teaching their own classrooms. This kind of perception has always been a concern for student teacher in identifying the effective aspects of teaching and learning process.

\section{Their perceptions of how to adapt to ESP students' needs}

Student teachers' perception of school teachers effectiveness might be about the question of "to what extent school teachers' changes and adaptation meets students' needs in the classroom setting. In teaching of one subpart of linguistic structure, can school teachers claim that they have taught the classroom if none of the students learn the points written in lesson plan? In this regard Jahnson (2003) believes if our students do not pick up the materials that school teachers try to convey, there will be ineffective situation. School teachers sometimes do not think of these situations, they only attempt to do the act of teaching and leave but these controversial issues are everlasting points existing at the heart of influential teaching. According to Tsui (2003) there is a difference between a good lesson plan and a good lesson. They are remarkably different from each other. Hassett (2000) states that school teachers teach so as to students will learn. If learning does not occur, teachers need to rethink of the problems and re-devise the employed strategies, innovate new ways, and as a whole do anything possible succeed in the teaching and learning process. It is reasonable to have a good methodology and lesson plan but it is vital to have students engaged in learning procedure. Thus student teachers will surely think of how to change and adapt the learning process in order to meet students' needs and achieve an effective teaching by school teacher in actual practice.

\section{Their perceptions of how to be reflective in ESP actual teaching}

Being reflective is one of the main influential aspects of effectiveness of teachers. Student teachers referring to their schooling experience and teacher education program might imagine being reflective as an important factor in school teachers' effectiveness whose classes are being taught by them. I this regard Chien (2002) claims that being reflective is perhaps the only infallible feature of good and effective school teachers, because without it, the other characteristics of effective teachers would be almost fruitless. Effective teachers think about and reflect in and on their methods, 
approaches, students, employed tasks and materials time and again. According to Li (2003) effective school teachers attempt to make comparisons and contrasts, make distinctions, revise, eradicate and restore. Being unable to consider what is taking place in actual classroom on a daily basis separates school teachers from the process of teaching and learning, since it is improbable to provide connectivity if school teachers themselves are not connected. Considering the process of teaching, being reflective is a crucial aspect of effectiveness of teachers for school teachers from the point of view of student teachers.

Their perceptions of how to enjoy their work and their students

It is obvious that teaching and learning setting should not be a strict place. It must be managed in a way that school teachers and students both feel relaxed and enjoy their times. In this regard Pianata (1999) declare that school teachers who are interested to their work and profession make their students motivated and creative. On the other hand, if school teachers do not enjoy their work, they consciously or unconsciously make their students lose their interest and motivation. Regarding Richardson (1996) enjoying has two sides. It might be enjoying the work and content and enjoying the students. There must be a balance between these two facets. If school teachers focus abundantly on content, it might make students misunderstood and lose their interests. In contrast, focusing excessively on students and ignoring the content may make students feel relaxed and satisfied but may hinder their learning process and subsequently students will not gain the educational goals in the determined period. Being able to harmonize between the enjoyment of students and the content is not an easy job. It might take a lot of time and energy. It requires school teachers to observe carefully, evaluate thoroughly ad reflect on their actions. Student teachers think of how school teachers manage their actual classes so that students and teachers both enjoy and feel comfortable and on their other hand gain the educational goals. This issue is one of the challenging perceptions of effectiveness of school teachers in actual practice.

\section{Methodology}

This part provides a thorough description of the research methodology used in this study. Firstly, for the sake of making an easy relationship between the various subparts of this section I will describe the research questions. Secondly, the educational context of the place in which the research was done is described and then the idea behind the employed research method will be taken into account in details. At last I will elaborate on the methodology details including participants,instruments, and data collection as well as data analysis procedures.

\subsection{Research Questions}

The current study investigates the perceptions of ESP teachers about the effectiveness of pre and in service teachers whose classes are taught by them during the teaching practice. In this regard their perceptions during teacher education program period and before taking part in actual classroom teaching practice and their perceptions after attending teaching practice are to be compared and contrasted. I attempt to find if there is any significant relationship between these two periods. In this regard research questions are as follows:

1. What are the perceptions of ESP teachers towards effective school teachers and their classes during teacher education program?

2. What are the perceptions of ESP teachers towards effective school teachers and their classes after taking part in actual teaching practice in their classes?

3. Is there any significant relationship between ESP teachers before teaching practice perceptions and after teaching practice perceptions?

\subsection{Educational Context}

This study is to be administrated in Zanjan University. This University is an international university located in Zanjan. The English Language Teacher Education as well as Persian Language Teacher Education programs are held in Education Faculty. English Language Teacher Education program includes Bachelor, Master of Art. The students are from various linguistic and cultural backgrounds. The medium of instruction is English. The undergraduate Students typically study for four years and take both general English and technical teaching courses. From their Fourth semester, student teachers are supposed to take two-credit practical teaching course in which they are to take part in actual classroom teaching practices and observe and teach.

\section{3., Research Design and Instruments}

The design of the study is both quantitative as well qualitative surveys. A questionnaire including questions of the ESPteacher's perceptions of the effectiveness of ESP teachers whose classes are being taught by them is given to student teachers. The statement in the questionnaire is questioning the eleven perceptions which were discussed in the previous parts. The statement in the questionnaire are rated using a five point Likert Scale ranging from one (the least) to five (the most). In addition to this quantitative research design, ESP teachers are asked to take part in interviews in which several questions are asked referring to the their perceptions of the effectiveness of ESP teaching practice. Questionnaire and interview are done twice, first time at the beginning of the course and then at the end of the course. The singlemoment study method is used in this study since one group of participants is evaluated in a 4 month interval. 


\subsection{Participants}

Participants are a group of 15 ESP teachers who are going to start their fourth semester in English language teacher education program in English Language Teaching Department of Zanjan University. They are selected from fourth semester student teachers since they have to take a two-credit practical teaching course as a must course. In this course, the student teachers are supposed to take part in theoretical discussion in course classes and attend actual ESP classroom teaching practices in which they will both observe and teach in the ESP classes for several sessions. This is exactly the main focus of this study, ESP teachers perceptions of effectiveness of ESP teachers' teaching practice before initiating the course and after finishing the course are compared and contrasted. The participants are chosen randomly. The important criteria for their selection is firstly being the fourth semester student of Teacher Education program in bachelor level and not having any sort of teaching experience. The participants are both male and female, but gender is not considered as an independent variable in this study.

\subsection{Data collection procedure}

This research method of this study is a single-moment procedure since only one group of student teachers as subjects of the study are investigated. Data are collected based on the quantitative questionnaire and qualitative interview. At the beginning of the fourth semester the participants are asked to fill in the questionnaire which includes statements about the perceptions of ESP teachers. They are supposed to rate the statements based Likret model ranging from the least to the most. Later, they are invited to take part in interview sessions in which they write their ideas about the perceptions which are given to them written in only titles without any extra explanation. In order to increase the validity of the data collection procedure and ascertain that they write what they know and believe, they are asked to write in their first language if they have any difficulty in conveying their ideas. In addition in order to eradicate test-wise factor, they are not informed that they will take the same procedure at the end of the course. Then, at the end of the semester, the same participants are asked to follow the same procedure. This time they have attended actual teaching practices for several sessions. Both semester beginning and ending data are collected and then analyzed.

\subsection{Data Analysis procedure}

The data taken from the questionnaires for student teachers for both semester beginning and ending are analyzed by the means of the recent version of Statistical Package of Social Science (SPPS.21). With the help of SPSS, the descriptive statistics including the Mean, the Percentage, the Frequency and the Standard Variation of the collected data are analyzed. In relation to the research questions and the significance of the relationship between the perceptions of ESP teachers before and after taking part in actual teaching practice, the data are analyzed by T-Test. T-Test is used to find if there is any significant relationship between ESP teachers' perceptions before and after attending actual teaching practice. In addition the written scripts of participants before and after course are analyzed and evaluated in details. The differences between various perceptions in two interviews are analyzed to identify whether their perceptions have changed or not. The results will help to the description and significance of findings of the questionnaire results.

\subsection{Discussion and conclusion}

It is obvious that an effective teacher education program in educational institutes and universities is ensured when the English language teaching departments and the schools are in close connection with each other. It is only in this way those ESP teachers have the opportunities to operationally define their theoretical and classroom bound knowledge. In the teacher education programs ESP teachers get knowledge of theoretical concepts and learn how to write lesson plans, manage the classroom, how to deal with classroom overloaded materials, how to tackle ambiguous situations, how to reflective, how to enjoy their work and their students, how to challenge with students' different expectation and how to deal with ESP students' success but these are all in theory. They need opportunities to shift to practice. Teaching practice is an appropriate opportunity to practice all these concepts in real life situation. Before initiating the teaching practice, student teachers have all certain perceptions of effectiveness of school teachers' procedures and teaching method. Being engaged in teaching practice will certainly verify or falsify those perceptions and they might get new attitudes and perceptions that they have never thought. Thus, the question of whetherESP teachers keep their former perceptions of effective teaching after having the experience of teaching practice or not and whether they find new perceptions are the main issues that these study attempts to take into consideration. Most of the time the perceptions of effectiveness of ESP teachers during teacher education program mismatches the perception that student teachers find after being engaged in actual teaching practice. This sort of disharmony might emerge from ESP teachers schooling experience as well as teacher education program.As a result, the aim of this study is identify what sort of perceptions ESP teachers of English language teaching have towards the effectiveness of school teachers whose classes are taught by them. Specifically speaking, the purpose of study is to recognize which of the eleven aforementioned perceptions are taking place in actual teaching. In other words, the study attempted to indicate which of the perceptions are considered as the criteria of effectiveness of ESP teachers' classes taught by them. It also attempts to find out if ESP teachers keep their perceptions of effective teaching or they revise it based on their new experience of ESP actual teaching practice. 


\section{References}

1. Bendl, S., Markova, K. \& Mojzisova, J. (2007) Integrated Model of student teaching practice, $32^{\text {nd }}$ Annual ATEE Conference England

2. Chien, Y. C. (2002). A study on the relationship between teacher efficacy andteaching effectiveness for the elementary school teachers. Unpublished masterthesis, Department of Education of National Taipei University of Education, Taiwan.

3. Constable, H. and Norton, J. (1994). Student teachers and their professional encounters. In I. Reid, H. Constable and R Griffiths (eds) Teacher Education Reforms: Current Research (PP.123-30). London : Paul Chapman

4. Crozier, G., Menter, I. \& Pollard, A. (1990). Changing Partnership. In M. Booth, J Furlong \& M. Wilkin (Eds.), Partnership in initial teacher training (PP. 44-56). London: Cassell.

5. Feng, L. Y. (2000). The study of the teaching effectiveness evaluation of the juniorhigh school teachers. Unpublished doctoral thesis, Graduate Institute ofEducation of National Kaohsiung Normal University, Taiwan.

6. Johnson, K. (2003). "Every experience is a moving force:" identity and growththrough mentoring. Teaching and Teacher Education, 19(8), 787e800.

7. Kyriacou, C. \& Stephens, P. (1999). Student teacher's concern during teaching practice, Evaluation and Research in Education, Vol. 13 (18-31), No. 1.

8. Li, C. Y. (2003). A study on students' perception of teachers' teaching styles andteaching effectiveness in industrialrelated upper secondary schools.

9. McNergney, R., \& Keller, C. (1999). Appendix. Some effective teachers' actions. In R.McNergney \& C. Keller (Eds.), Images of mainstreaming: Educating students withdisabilities(pp. 211-212). New York: Garland Publishing.

10. Ogonor, B.O. \& Badmus, M.M. (2006). Reflective teaching practice among student teachers: The case in a tertiary institution in Nigeria, Australian Journal of Teacher Education, Vol.31, No.2.

11. Pianata, R. C. (1999). Enhancing relationships between children and teachers. Washington, DC: American Psychological Association.

12. Richardson, V. (1996). The roles of attitudes and beliefs in learning to teach. In J. Sikula, T. J.

13. Buttery, \& E. Guyton (Eds.), Handbook of research on teacher education (2nd ed., pp.102-119). New York: Macmillan.

14. Stephens, P. (1996). EssentialMentoring Skills: A practical handbook for school based Teacher Educations, Cheltenham: Stanley Thorness.Tsui, A. (2003). Understanding expertise in : Case studies of ESL teachers. NewYork: Cambridge University Press.

15. Wenger, E. (1998).Communities of practice: Learning, meaning, and identity. Cambridge: Cambridge University Press.

16. Young, H. P. (1998). Individual strategy and social structure: An evolutionary theory ofinstitutions. Princeton, NJ: Princeton University Press. 